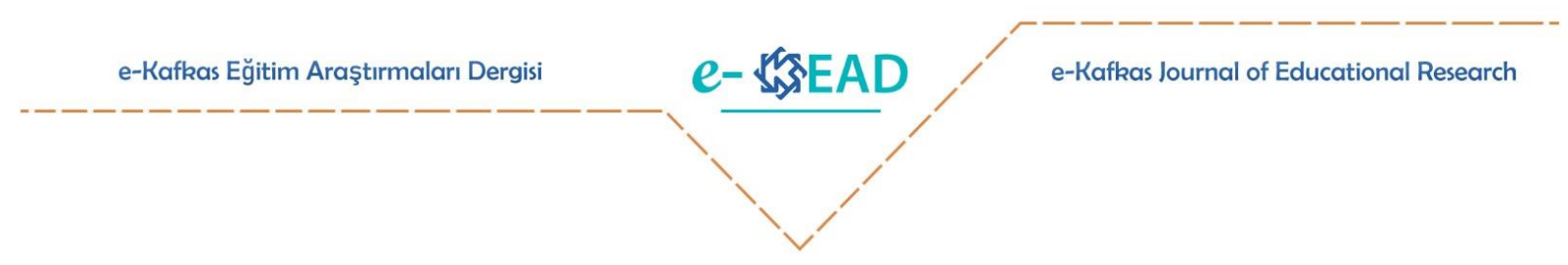

\title{
Farklı Branş Öğretmenlerinin Duygusal Zekâ Yeteneklerinin Akademik İyimserlik ve Psikolojik Dayanıklılık Üzerine Etkisi*
}

\author{
Abdurrahman Kasım PAKIŞ (iD Mehmet Engin DENİZ
}

Atıf: Pakiş, A. K. ve Deniz, E. M. (2020). Farklı branş öğretmenlerinin duygusal zeka yeteneklerinin akademik iyimserlik ve psikolojik dayanıklılık üzerine Etkisi, e- Kafkas Araştırmaları Dergisi, 7, 153-166.

doi:10.30900/kafkasegt.752595

Araştırma Makalesi

Geliș Tarihi: 13.06 .2020

Kabul Tarihi:09.07.2020

\section{Öz}

Duygusal zekâ bireyin kendisinin ve başkalarının duygularını tanıma, izleme, yönlendirme ve bu duyguları çevresindeki ilişkilerde olumlu bir şekilde kullanma yeteneğidir. Akademik iyimserlik akademik çevreye ilişkin algılarla oluşmaktadır. Psikolojik dayanıklılık ise stresle yakından ilişkili bir kavram olup stresli durumlarda gösterilen direnci ortaya koyar. Bu çalışmanın amacı, farklı branş öğretmenlerinde duygusal zekânın akademik iyimserlik ve psikolojik dayanıklılık üzerindeki etkisinin belirlenmesidir. Bu amaçla tanımsal nitelikte bir araştırma tasarlanmıştır. Araştırmada nicel veri toplama yöntemlerinden yüz yüze anket yöntemi kullanılmış̧ır. Araştırmaya 709 öğretmen katılmıştır. Araştırmaya katılan öğretmenlerin 370'i kadın, 339'u erkektir. 709 katılımcı öğretmenden toplanan veriler frekans dağılımları ve basit doğrusal regresyon analizi ile test edilmiştir. Araştırma bulgularına göre duygusal zekânın akademik iyimserlik üzerinde negatif, psikolojik dayanıklılık üzerinde ise pozitif yönlü anlamlı etkileri tespit edilmiştir. Diğer bir ifadeyle duygusal zekâ yetenekleri yüksek öğretmenlerin akademik iyimserlikleri düşük, duygusal zekâ yetenekleri yüksek öğretmelerin psikolojik dayanıklılık düzeyleri yüksek çıkmışır.

Anahtar Sözcükler: Duygusal Zekâ, Akademik İyimserlik, Psikolojik Dayanıklılık

\begin{abstract}
Emotional intelligence is the ability of the individual to recognize, follow, direct and feel the emotions of her/himself and others and to use these emotions positively in the relationships around her/him. Academic optimism consists of perceptions about the academic environment. Psychological resilience is a concept closely related to stress and reveals the resistance shown in stressful situations. The aim of this study is to determine the effect of emotional intelligence on academic optimism and psychological resilience in different branch teachers. For this purpose, a descriptive research was designed. In the research, face-to-face survey method, one of the quantitative data collection methods, was used. 709 teachers participated in the research. 370 of them are women and 339 are men. Data collected from 709 participant teachers were tested by frequency distributions and simple linear regression analysis. Findings indicated that negative effects of emotional intelligence on academic optimism and positive effects on psychological resilience were determined. In other words, teachers with high emotional intelligence abilities have low academic optimism, and teachers with high emotional intelligence abilities have high psychological resilience.
\end{abstract}

\footnotetext{
* Bu çalışma İstanbul Sabahattin Zaim Üniversitesi Sosyal Bilimler Enstitüsü bünyesinde yürütülen "Farklı Branş Öğretmenlerinin Duygusal Zekâ Yeteneklerinin Akademik İyimserlik ve Psikolojik Dayanıklılık Üzerine Etkisi” isimli yüksek lisans tez çalışmasının bir bölümünden türetilmiştir.
} 
Keywords: Emotional Intelligence, Academic Optimism, Psychological Resilience

\section{Giriş}

Bir toplumun, bir ülkenin ihtiyacı olan insan gücünün yetişmesinden eğitim sisteminin en önemli ögesi olan öğretmen sorumludur. Yapılan 2.000'i aşkın araştırmada öğretmenlerin öğrencilere sadece eğitsel yönden değil aynı zamanda edindiği tutum, davranış yönünden de rol model olduğu belirlenmiştir (Küçükahmet, 2010). Öğretmen fark yaratabilir mi? Yıllardır üzerine çok fazla tartışılan bir konu. Yapılan çalışmalar açıkça gösteriyor ki bir öğretmen kesinlikle fark yaratabilir. Eski bir öğretim kuralı şöyle der; gayret ve istek öğretilmez, bulaşır. Bu söz öğretmenlerin toplumdaki yerini bir nebze ortaya koymaktadır. Toplum devamlı dinamik bir yapı içerisindedir. Dolayısıyla öğretmenler yeniliğe açık olmak, geleneksel eğitim yaklaşımlarının ötesinde modern eğitim yaklaşımlarını benimsemek durumundadırlar. 2001 yılında yapılan bir çalışmada okul öncesi bir öğretmenin öğrenci ile olan ilişkisinin öğrencinin sekizinci sınıfa kadar olan akademik başarı ve davranışları üzerinde (özellikle davranışsal problemi olan çocuklarda) ve de bilişsel kapasitenin artırılmasında etkili olduğu saptanmıştır. Sözü geçen çalışmanın bulgularına göre eğer öğretmenler eğitim sürecinin başlarında problemi olan öğrencileri tespit eder ve onlarla iyi ilişkiler kurup onların gerek eğitsel gerek davranışsal problemleri üzerinde titizlikle dururlarsa çocukların hem akademik başarıları hem de yaşam kaliteleri artacaktır (Selçuk, 2018).

Alanının temel konularına hâkim olmayan, perspektif kazanamamış, alandaki temel konuları ve aralarındaki ilişkileri yakalayamayan öğretmenlerin profesyonel davranması elbette beklenemez (Özden, 2014). Öğretmenlerin öğrenciler üzerinde olumlu bir etki bırakabilmeleri için birtakım becerilere sahip olmaları gerekir. Diğer bir ifadeyle hem bilgi birikimlerinin hem de kişilik özelliklerinin öğrencileri olumlu yönde etkileyebilmesi için öğretmenlerin sadece zeki değil aynı zamanda duygusal açıdan da belirli bir kapasitenin üzerinde olmaları gerekir (Küçükahmet, 2010).

Bir öğretmenin inanç ve tutumu ne kadar öğrenci merkezli olursa akademik iyimserliği de o kadar yüksek olur. Benzer şekilde, öğretmenin genel olarak iyimser oluşu akademik iyimserliği de beraberinde getirir. Öğrenci merkezli öğretim inançları akademik iyimserliğinin önemli bir belirleyicisi olarak ortaya çıkmaktadır (Ngidi, 2012). Öğretmenler öğrencilere yalnızca akademik bilgileri aktarmakla kalmaz aynı zamanda onların kişisel gelişimleri hatta yaşam doyumları üzerinde etki bırakırlar. Dolayısıyla bir öğrencinin yaşamında mutlu olmasında da mutsuz olmasında da öğretmenin payı bulunabilir. Bir bireyin sorumluluğunu almak öğretmenlerde strese neden olabilecek en önemli faktörler arasındadır. Bir öğretmen için öğrencilerinin gerek akademik başarıları gerek sosyal yönden gelişimleri, sağlı durumları, aile ilişkileri vb. oldukça önemlidir. Şu hâlde öğretmen öğrencinin yaşantısındaki olumlu veya olumsuz etkilere fazlasıyla duyarlıdır. Bu durum, öğretmenlerde psikolojik dayanıklılığa gereksinimi bir kat daha artırmaktadır.

Eğitimin en genel amacı bireyleri topluma faydalı hale getirmektir. Bu amaca hizmet etmek için eğitimde en önemli rol öncelikle aileye daha sonra bireylerin örgün eğitim aldığı kurumlara düşmektedir. Bireylerin yetişmesinde öğretmenlerin önemli bir payı vardır; öğretmenler eğitim sisteminin temel taşıdır. Öğretmenlerin kişilikleri, tutum ve davranışları hakkında iki binden fazla çalışma yapılmıştır. Bu çalışmalar, öğretmenlerin eğitim kurumlarında öğrencileri etkiledikleri ve öğrencilerin gelişim ve öğrenme hayatlarında önemli bir iz bıraktıklarını net bir şekilde ortaya koymuştur (Küçükahmet, 2010).

Araştırmalar öğretmen ve öğrenci ilişkisinin çok önemli olduğunu vurgular. Yapılan bir çalışmada anaokulunda okuyan öğrencilerin öğretmenlerle olan ilişkilerinin gelecek sekiz yıllık eğitim hayatında belirleyici bir faktör olduğunu açıklamıştır. Bu çalışmaya göre; eğitim ve öğretimin başlarında öğrencilerin ihtiyaçları doğru analiz edilir ve problemli davranışlara yönelik çalışmalar oluşturulursa ilerleyen dönemlerde öğrenci davranış ve tutumlarında düzelme olduğu, tersi durumda ise olumsuz davranışlarda artış olduğu belirlenmiştir (Hoy, 2010).

Duygusal zekâ kavramına giriş yapmadan önce duygu ve zekâ kavramları basit bir şekilde tanımlanacaktır. Duygu kavramı psikologlar ve felsefecilerin sıklıkla araştırdıkları ve kesin anlamı üzerinde tartıştıkları bir kavramdır. Genel bir tanım olarak duygu kavramı "bir his ve bu hisse özgü belli düşünceler, psikolojik ve biyolojik haller ve bunlara yönelik bir dizi hareket eğilimleri"dir (Goleman, 2007, s. 373). 
Duygular gerek gündelik gerekse iş ve sosyal yaşamın ayrılmaz bir parçasıdır. Bu yüzden özellikle yaşadığımız modern dünyada bireylerin duygularını anlaması ve düzenlemesi çok önemlidir. Aristo der ki "herkes kızabilir; bu kolaydır. Ancak doğru insana, doğru ölçüde doğru zamanda, doğru nedenle ve doğru şekilde kızmak, işte bu kolay değildir." (Goleman, 2019, s. 19). Zekâ kavramı benzer şekilde üzerinde yıllardır çalışılan bir kavramdır. Zekâ kavramına ilişkin genel bir tanım vermek gerekirse Wechlser'nin ortak tanımı ele alınabilir. Wechlser'e göre zekâ "dünyayı anlayabilme, düşünebilme, zorluklarla karşılaşıldığında kaynakları etkin şekilde kullanabilme yeteneğidir." (Çakar ve Arbak, 2004, s. 26).

Duygusal zekâ kavramını ilk kez Salovey ve Mayer, 1990 yılındaki çalışmalarında kavramsallaştırmışlardır. Buna göre duygusal zekâ "kendisinin ve başkalarının duygularını anlama, değerlendirme yeteneği ve bu yeteneği eylemlere dökerek kullanma becerisi” şeklinde tanımlanabilir (Salovey ve Mayer, 1989, 1990, s. 185). Salovey ve Mayer, bireyin duygusal açıdan zeki olarak nitelendirilebilmesi için dört alanda yetenekli olması gerektiğini söyler. Bunlar; duygularını tanımlama, duyguları kullanma, duyguları anlama ve duyguları düzenleme yeteneğidir. Açıklanan duygusal zekâ yetenekleri doğrultusunda öğretmenin öz bilinç, duyguları yönetme, empati, motivasyon ve sosyal becerilere sahip olmasının, işteki başarısını ve yaşam kalitesini artıracağı, bunun da öğrencilerle daha iyi ilişkiler kurmayı sağlayacağı düşünülmektedir (Salovey ve Mayer, 1989, 1990).

\section{Duygusal Zekâ}

Günümüzde bireyler, toplumsal yaşamda çok sayıda insanla farklı etkileşimler içerisindedirler. $\mathrm{Bu}$ durum farklı toplumsal rollerin varlığını ortaya çıkarmaktadır. $\mathrm{Bu}$ rollerinin gerekliliklerini başarabilmiş olmak, bireyin hem özel hem de profesyonel yaşantısı üzerinde belirleyicidir. Bu rollerin başarılmasında bilişsel zekâ (IQ) potansiyelinin yetersiz kaldığı, duygusal zekânın günümüzde bunu desteklediği bilinmektedir (Deniz ve Yılmaz, 2004).

Öğretmenlerin duygusal zekâ yetkinlikleri öğretim ortamında çok önemlidir. Daniel Goleman "İş Başında Duygusal Zekâ" kitabında, yeni nesil çocukların bilişsel zekâlarının yükseldiği, bunun yanında duygusal zekâlarının düştüklerini belirlemiş ve bunun sonucu olarak çocuklarda yalnızlık, bunalım, öfke, sinir, endişe ve saldırganlık dürtülerinin arttıklarını belirtmiştir (Goleman, 2019). Böyle bir ortamda öğretmenlere büyük rol düşmektedir. Öğretmenler öğrencilerine duygularını düzenleme ve akılc1 kullanma yetisini kazandırabilirler; ancak bu yetilerin öncelikle öğretmenlerde bulunmas1 gerekir. Duygusal zekâ kavramını birçok bilim adamı farklı şekilde tanımlamıştır. Bu tanımların birkaçına aşağıda yer verilecektir. Duygusal zekâyı en temel anlamda "bireyin duygularını akılcı kullanması, gerek özel yaşantısında gerekse sosyal hayatında duygularını düzenleyebilme ve akıllıca kullanabilme yeteneği" olarak tanımlayabiliriz. Duygusal zekâ yeterlilikleri yüksek kişiler, duyguları daha iyi kavramakta ve yönetmektedirler (Deniz, Erus ve Büyükcebeci, 2017).

Duygusal zekâ, kendimizi ne kadar etkili bir şekilde anladığımızı ve ifade ettiğimizi, başkalarını ne kadar anladığımızı ve onlarla ilişki kurduğumuzu ve günlük taleplerle ne kadar başa çıkabildiğimizi belirleyen birbiriyle ilişkili duygusal yetkinliklerin, becerilerin ve kolaylaştırıcıların bir kesitidir (Bar-On, 2006). Bariso kitabında; duygusal zekâyı bir yetenek olarak görür ve bu yeteneği de kişinin duygularını aleyhine değil lehine kullanma becerisi olarak açıklar (Bariso, 2019). Yeşilyaprak, duyguların her insanda var olduğunu ancak duygusal zekânın bir yetenek olduğunu söyler ve duygusal zekâyı; "bireyin duygularını akıllıca, duyarlı ve bilgece kullanma yetisi" olarak tanımlar (Yeşilyaprak, 2001, s. 140).

Cooper ve Sawaf çıkardığı "Liderlikte Duygusal Zekâ" kitabında duygusal zekâ tanımını şöyle vermektedir; "duyguların gücünü ve hızlı algılayışını, insan enerjisi, bilgisi, ilişkileri ve etkisinin bir kaynağı olarak duyumsama, anlama ve etkin bir biçimde kullanma yeteneğidir." (Cooper ve Sawaf, 2000, s. 12). Daniel Goleman duygusal zekâ kavramını, "kendimizin ve başkalarının hislerini tanıma, kendimizi motive etme, içimizdeki ve ilişkilerimizdeki duyguları iyi yönetme becerisi" olarak tanımlar (Goleman, 2019, s. 389). Goleman, bu kavrama yönelik birtakım yeterlilikler açıklamıştır. Bunlar; öz bilinç, kendini düzenleme, motivasyon, empati ve sosyal becerilerdir.

Öz Bilinç: Bireyin öznel duyguları, güçlü ve zayıf tarafları, ihtiyaçları ve güdülerini anlamlı bir şekilde kavrama yeteneğidir. Öz bilinci yüksek olan bireyler aşırı eleştirelliğe veya gerçekten uzak 
umutsuzluğa kapılmazlar. Aksine bu bireylerin hem kendilerine hem de başkalarına karşı dürüst oldukları bilinmektedir. Öz bilinci yüksek olan insanlar kendilerine daha fazla güvendiklerinden iş performansları da genelde yüksek olmaktadır (Goleman, 2019).

Kendini Düzenleme: Biyolojik dürtülerimiz duygularımıza yön veren uzuvlardır. Onları yok saymak çoğu zaman mümkün olmaz ancak onları düzenleyebilirsek dürtülerimizin bize yansıması olumlu olur. Duygularımızı düzenleme yeteneği bizi duygularımızın esiri olmaktan kurtarır ve ne hissetmemiz, nasıl hissetmemiz gerektiği yönünde bize yol gösterir (Goleman, 2007).

Motivasyon: Kişinin duygularını bir amaç doğrultusunda toparlama, dikkat edebilme, kendini harekete geçirebilme, kendine hâkim olabilme ve yaratıcılık için duygularını kullanma yeteneğidir (Bariso, 2019, s. 73). Bu yetisi yüksek olan bireyler engellenmiş̧lik hissine kapılmadan işlerini düzenleyebilirler. Hayat karşısında sebat etmeyi bilen kişilerdir. Her durumdan bir ders çıkarır ve motivasyonlarını yüksek tutarak azimli bir şekilde başarıya ulaşırlar (Goleman, 2019). Birey için en uygun motivasyon seviyesi, stres ve baskıyla başa çıkmada önemli bir psikolojik gereklilik olarak görülmektedir (Sarkar ve Fletcher, 2014).

Empati: Bir kişinin kendi duygularından ziyade karşı tarafın duygularını anlama yeteneği olarak açıklanabilir. Kişinin karşısındakinin neler hissettiğini anlaması için kendisini onun yerine koyabilmesi ve onun bakış açısından bakabilme yeteneğidir. Empati, insanlarla ilişkilerde temel beceridir. Empatik kişiler, başkalarının neler hissettiklerini, neye ihtiyaçları olduğunu gösteren belli veya belirsiz sinyalleri alabilirler. $\mathrm{Bu}$ da onları kurdukları ilişkide ve hayatlarında daha başarılı kılar. Özellikle öğretmenlik mesleğinde olmak üzere empatik bireyler, iş yaşamlarında daha başarılıdırlar (Bariso, 2019).

Sosyal Beceriler: Bireyin çevresindeki ilişkileri iyi idare edebilme, sosyal durumları ve ağlarını doğru algılama, pürüzsüz etkileşim içinde olma yeteneğidir (Goleman, 2019). Bireyin bu becerileri; ikna ve liderlik ederek kullanmak, bireyler arası çatışmalarda arabuluculuk etmek, ekip çalışmalarında liderlik etmek olarak sıralanabilir.

\section{Akademik İyimserlik}

İyimserlik, bireyin yaşamında sübjektif olarak değişen yaşam koşullarına rağmen zaman ve ortamdan bağımsız bir şekilde durumunun olumlu olduğuna ve olumlu olacağına yönelik bireyin inanç ve tutumu olarak ele alınabilir. İyimserlik kavramı kişilerin geleceklerine yönelik güven duyguları beslemeleri ve kendilerini geleceğe yönelik olumlu şeyler bekleyeceği inancını kapsar (Gillham ve Reivich, 2004). Karacaoğlu ve Köktaş, iyimserliği hastane çalışanları üzerinde incelemişlerdir. Buna göre çalışanların, hastalar ve hasta yakınlarıyla iyimser bir iletişim içinde olmaları beklenmektedir (Karacaoğlu ve Köktaş, 2016).

Akademik iyimserlik, öğretmenlerin kendi okullarında öğretme ve öğrenme konusundaki iyimserliğidir. Öğretmenlerin akademik iyimserlik düzeylerinin yüksek olması öğrencilerin başarılarını olumlu yönde etkilemektedir (Yıldırım ve Yılmaz, 2018).

Akademik iyimserlik; akademik vurgu, güven ve yeterlilik duygusu olmak üzere üç boyutta açıklanmıştır. Bu boyutlar arasındaki ilişki, şekildeki gibi gösterilmiştir. (Hoy vd., 2008).

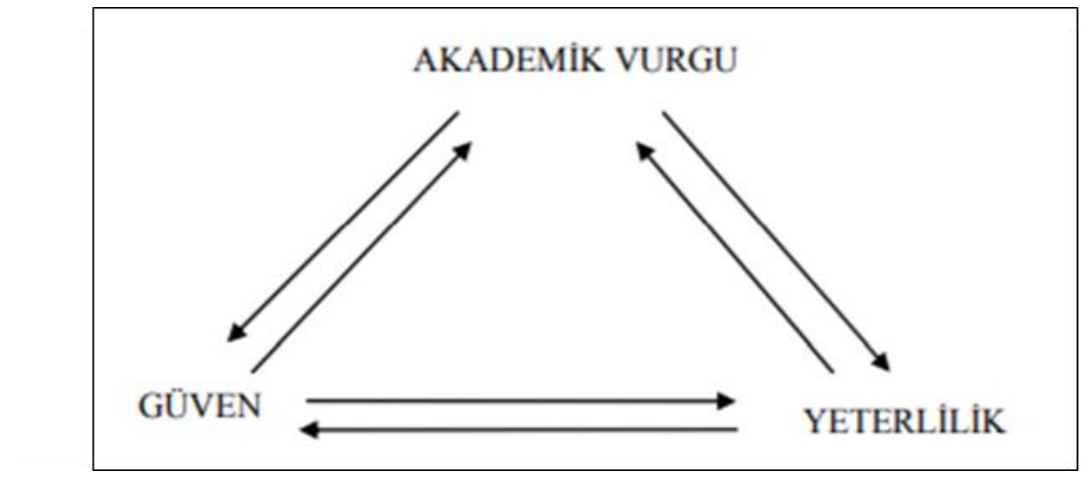

Şekil 1: Akademik İyimserliğin Alt Boyutları 
Akademik vurgu: Akademik vurgu birçok ülkede okulların başarısıyla ilişkilendirilir. Akademik vurgu bir öğretmenin öğrencilerini akademik olarak meşgul etme, onlara akademik çalışma verme yetisi olarak açıklanır. Bu yeti öğrencilerin okulda geçirdiği zamanlarının kaliteli olması için çok önemlidir ve bu yetisi güçlü olan öğretmenler öğrencilerin okulda geçirdiği zamanları en etkili şekilde kullanan öğretmenlerdir. (Woolfolk, 2010).

Güven: Duygusal bir boyut olan güven akademik iyimserliğin alt boyutlarındandır. Ebeveynlerin ve öğrencilerin öğretmene olan güven duygusunun yüksek olması, öğrencilerin sosyoekonomik durumuna bakılmaksızın akademik başarıyı yükseltmenin bir yolu olarak görülür (Henderson ve Mapp, 2002). Öğretmenlerin görev yaptığı bir okulda öğrenciler ve ebeveynlerinde güven, öğrenci başarısını olumlu etkiler (Kirby, 2009).

Yeterlilik: Yeterlilik bir bireyin bir işi yapabilecek özelliklere sahip olmasını ifade etmektedir. Yeterlilik kavramı aynı zamanda bireyin bir işi gerçekleştirmek için kendinde algıladığı öznel değerlendirmeleri içerir. Yeterlilik, bireylerin yaşamlarında karşılaştıkları olumsuz durumlara karş1 verebilecekleri mücadelelerin üstesinden gelme konusunda ne düzeyde başarılı olabileceklerine dair olumlu inanç ve tutumlarından oluşur (Bozkurt ve Ercan, 2017).

Akademik iyimserliğin bu üç boyutu da birbirleriyle ilişkilidir. Okul ortamında güven sağlandığı zaman velilerin öğrencilere ve öğretmenlere olan inancı artar, bu durum yeterlilik duygusunu teşvik eder. Aynı şekilde okul ortamında güven sağlandığı zaman öğretmenler, aileler tarafından olumlu dönütler alırlar bu da okulun akademik standartlarını yükseltir. Okulların öğrenci merkezli başarı etkinlikleri düzenleme yetisi arttıkça, okulların akademik vurgu, güven ve yeterlilik boyutları da güçlenir. Bu durum okulun akademik iyimserlik düzeyini olumlu şekilde etkiler (Çoban ve Demirtaş, 2011).

\section{Psikolojik Dayanıklıık}

Dayanıklılık kavramı kişilerin zorluklar, değişimler ve riskli durumlar karşısında olumlu bir şekilde bu durumların üstesinde gelme yeteneği, becerisi olarak tanımlanır. Dayanıklılık pozitif psikolojik bir kapasitedir, zaman içerisinde değişimler meydana gelebilir ancak bireyler çevresel faktörlerin etkisi ile bu değişimlerin üstesinden gelebilirler (Stewart, Reid ve Magham 1987). Dayanıklılık, değişim veya belirsizlik durumlarıyla başa çıkmayı sağlayan bilişsel, duygusal ve sosyal yetileri içerir (Windle, Markland ve Woods, 2008).

Psikolojik dayanıklılık, stres barındıran durum ve olaylar karşısında direnç göstermeyi sağlayan bir özelliktir (Terzi, 2008). Kimi bireyler genetik özellikleri sayesinde stresli yaşam olaylarına daha fazla direnç göstermektedirler (Kanbur, Kanbur ve Özdemir, 2017). Psikolojik dayanıklılığı yüksek bireylerin stres eşiğinin daha yüksek olduğu bilinir, dolayısıyla çatışma, kriz, değişim ve diğer kritik koşullarda daha yüksek motivasyonla performans göstermeleri beklenir (Bitmiş, Sökmen ve Turgut, 2013). Psikolojik dayanıklılık kavramı; bağlanma, güçlük ve kontrol olmak üzere 3 alt boyuttan oluşan kişilik özelliğidir (Crowley, Hayslip ve Hobdy, 2003).

Bağlanma: Bağlanma, kişinin hayatın farklı taraflarıyla ilgilenme yönelimi şeklinde tanımlanabilir. Bireyin sosyal çevresi, iş çevresi ve ailesi gibi farklı ortamlarda karşılıklı ilişkileri, sahip olduğu inanç, tutum ve değer yargılarına bağlanması, yaşamının tüm boyutlarında ortaya çıkmakta ve bu durum kişinin stresli durum ve olaylar ile mücadele edebilmesi için gereken bir güç kaynağı oluşturmasını sağlamaktadır. Bağlanma düzeyi yüksek kişiler, kendilerini ve çevrelerini ilginç ve zaman harcamaya değer olarak değerlendirirler. Dolayısıyla yaptıkları her şeyde meraklarını giderecek anlamlı unsurları tespit edebilirler (Iş̧k, 2016). Kişinin sürmekte olduğu hayatı anlamlı bulması, bir amaç edinmesi ve yaşama bağlılığı sonucunda elinden gelenin en iyisini yapmasıdır (Durak, 2002).

Kontrol: Psikolojik dayanıklılığın kontrol boyutu, olayların ve bireysel tepkilerin denetlenebilirliğine yönelik inançla ilişkilidir. Bu inanca sahip olanlar, stres yaratan durumu kontrol edebileceklerini ve bunu kendi lehlerine dönüştürebileceklerini düşünürler. Kontrol boyutu, özdenetim, başarı güdüsü, otonomi ve istekli olma kavramları ile bağdaştırılır (Motan ve Gençöz, 2009).

Güçlük: Psikolojik dayanıklılık literatürüne göre değişim, günlük yaşamın bir parçasıdır. Değişim, bir tür güvenlik riskinden çok bireyi gelişime yönlendiren bir etki olarak ele alınmaktadır. 
Güçlük boyutu, bireyin değişime uyum sağlayabilmesi ve değişim sürecini kendini geliştirmek için firsat olarak görebilmesinden ibarettir (Kayac1 ve Özbay, 2016).

Yukarıdaki açıklamalar doğrultusunda bu çalışmada; duygusal zekânın akademik iyimserlik üzerinde ve duygusal zekânın psikolojik dayanıklılık üzerinde anlamlı bir etkisi olup olmadığı incelenmiş ve aralarındaki ilişki incelenmiştir. Bu doğrultuda yapılan çalışmaların sonuçları aşağıda verilmiştir.

\section{Yöntem}

Bu bölümde araştırma modeli, araştırma grubu, veri toplama araçları, işlem ve veri analiz sürecine ilişkin bilgiler verilmektedir.

\section{Araştırma Modeli}

Araştırma tasarımı, tarama araştırma türüne örnek teşkil etmektedir. Tarama araştırmaları çoğunlukla mevcut durumu analiz etmektedir. Tarama araştırmalarında araştırmacı, daha geniş bir kitle üzerinde çalışmaktadır. Veri toplama esnasında katılımcının yönlendirilmesi söz konusu değildir. Tarama araştırmaları, ölçülen fenomenler arasındaki ilişkilerin incelenebildiği modellerdir (Büyüköztürk vd., 2016).

\section{Araştırma Grubu}

Araştırmaya Hakkâri il merkezi ve Yüksekova ilçesinde, Milli Eğitim Bakanlığında görev yapan toplam 709 öğretmen katılmıştır. Araştırmaya katılan öğretmenlerin 370(52.2)'i kadın, 339(47.8)'u erkektir. Katılımcıların \%19.9'u (141 kişi) 21-25 yaş, \%52.3'ü (371 kişi) 26-30 yaş, \%18.9'u (134 kişi) 31-35 yaş, \%7.1'i, (50 kişi) 36-40 yaş, \%1.3'üu (dokuz kişi) 41-45 yaş ve \%0.6's1 (dört kişi) 46-50 yaş aralığındadır.

\section{Veri Toplama Araçları}

Kişisel bilgi formu: katılımcıların cinsiyet, yaş, medeni durum, öğrenim durumu, görev yaptığ1 okul türü ve branşını belirlemek amacıyla tarafımızdan hazırlanmıştır.

Duygusal Zekâ Ölçeği: Bu makalede duygusal zekâ ölçeğinin kısa formu kullanılmıştır. Petrides ve Furnham tarafından geliştirilen Duygusal Zekâ Özelliği Ölçeği-Kısa Formu (DZÖÖ-KF), Deniz, Özer ve Işı1k (2013) tarafından Türkçeye uyarlanmıştır. DZÖÖ-KF, bireyin duygusal yeterlikleriyle ilgili kendini algilama düzeyini belirlemek üzere geliştirilmiş bir ölçek olup toplam 30 maddeden oluşmaktadır (Deniz, Özer ve Işık, 2013).

Akademik İyimserlik Ölçeği: Akademik iyimserlik ölçeği orijinalinde, kolektif yeterlilik, güven ve akademik vurgu alt boyutlarından oluşmaktadır. Kerimgil ve Gürol 2013 yılında ölçeği Türkçeye uyarlamışlardır. Uyarlanmış ölçekte faktörlerin geçerliliği faktörler arası korelasyonla tespit edilmiştir.

Psikolojik Dayanıklılık Ölçeği: Bu araştırmada psikolojik dayanıklılık, Gürgân tarafından geliştirilen ve 50 ifadeden oluşan ölçekle ölçülmeye çalışılmıştır (Gürgân, 2006). Bu ölçekte yer alan ifadeler üç boyut altında toplanmıştır. Bunlar; güçlü olma ve iyimser olma/yaşama bağlı olma, araştırıcı olma ve öngörülü olma ve girişimci olma ve iletişim/ilişki kurma olarak ortaya çıkmıştır.

\section{Veri Analiz Süreci}

İlk olarak araştırmaya katılanların demografik özelliklerini ortaya koymak üzere frekans dağılımlarına bakılmıştır. Sonrasında ise duygusal zekânın akademik iyimserlik ve psikolojik dayanıklılık üzerindeki etkisini test etmek amacıyla basit doğrusal regresyon analizi yapılmıştır. Bu araştırma, Hakkâri ilinde yalnızca Merkez ve Yüksekova ilçelerini kapsamaktadır. Ayrıca araştırmanın yürütüldüğü süreçte ortaya çıkan Covid-19 salgını nedeniyle ciddi bir zaman kısıtlılığıyla karşılaşılmıştır. Milli Eğitim Bakanlığı'nda görev yapan öğretmenlere yüz yüze anket uygulandığından, uzaktan eğitime geçilen süreçte veri toplamaya devam etmek mümkün olmamıştır. 


\section{Bulgular}

Duygusal zekânın akademik iyimserlik üzerindeki etkisini gösteren basit doğrusal regresyon analizi sonuçları Tablo 1'de görülmektedir.

Tablo 1.

Duygusal Zekânın Akademik İyimserlik Üzerindeki Etkisini Gösteren Basit Doğrusal Regresyon Analiz Sonuçları

\begin{tabular}{llllll}
\hline $\mathrm{R}^{2}$ & $\mathrm{~F}$ & $\mathrm{p}$ & Beta & $\mathrm{t}$ & $\mathrm{p}$ \\
& & & & & \\
\hline 0.092 & 73.038 & 0.000 & -0.274 & -8.546 & 0.000 \\
\hline Sabit: 3.882 & & & & & \\
\hline
\end{tabular}

Tablo 1'de görüldüğü üzere, akademik iyimserliğin \%9.2'si duygusal zekâ tarafından açıklanmaktadır. Duygusal zekânın akademik iyimserlik üzerindeki etkisi negatif olarak tespit edilmiştir. Bu bağlamda; duygusal zekâ ortalamaları yüksek olan öğretmenlerin, mesleki ve kurumsal beklentilerinin yüksek olduğu düşünülmektedir. $\mathrm{Bu}$ durum, akademik anlamda doyum sağlanamamasına neden olabileceğinden, duygusal zekâ ortalaması arttıkça akademik iyimserliğin düştüğü gözlenmiştir. Regresyon modeli şu şekilde kurulabilir:

Akademik İyimserlik $=3.882-0.274 \times$ Duygusal Zekâ

Duygusal zekânın psikolojik dayanıklılık üzerindeki etkisini gösteren basit doğrusal regresyon analizi sonuçları Tablo 2'de görülmektedir.

Tablo 2.

Duygusal Zekânın Psikolojik Dayanıklılık Üzerindeki Etkisini Gösteren Basit Doğrusal Regresyon Analiz Sonuçları

\begin{tabular}{llllll}
\hline $\mathrm{R}^{2}$ & $\mathrm{~F}$ & $\mathrm{p}$ & Beta & $\mathrm{t}$ & $\mathrm{p}$ \\
& & & & & \\
\hline 0.275 & 269.058 & 0.000 & 0.574 & 16.403 & 0.000 \\
\hline
\end{tabular}

Sabit: 1.565

Tablo 2'de görüldüğü üzere, psikolojik dayanıklılığın \%27.5'i duygusal zekâ tarafindan açıklanmaktadır. Duygusal zekânın psikolojik dayanıklılık üzerindeki etkisine ilişkin regresyon modeli şu şekilde kurulabilir:

Psikolojik Dayanıkl11ık $=1.565+0.574 \times$ Duygusal Zekâ

\section{Tartışma, Sonuç ve Öneriler}

Yapılan çalışmalara bakıldığında literatürde doğrudan duygusal zekânın akademik iyimserlik üzerindeki etkisine dair çalışmaya rastlanmamıştır. Ancak duygusal zekâ ile iyimserlik (optimizm) arasındaki korelasyon sıklıkla ele alınmıştır. Optimizm, ileride olumlu sonuçlarla karşılaşılacağına, pesimizm ise olumsuz sonuçlarla karşılaşılacağına dair beklentilerdir. Pesimizm depresif duygu durumunu artırırken optimizm düşük depresif duygu durumu sağlamaktadır. Başka bir deyişle, iyimserlik veya kötümserlik psikolojik iyi oluşla ilintili kavramlardır (Augusto Landa, Pulido-Martos ve Lopez-Zafra, 2011). Duygulara dair yetenekleri kullanma konusunda gelişmiş bireylerde, optimist bakış açısı da bir nevi kendiliğinden gelişmektedir (Rey ve Extremera, 2014). Kumcağı, Çelik ve Y1lmaz, üniversite öğrencilerinin duygusal zekâ yeteneklerinin iyimserlik üzerine etkisini inceledikleri çalışmalarında, duygusal zekânın iyimserlik üzerinde pozitif anlamlı bir etkisi olduğunu saptamışlardır (Kumcağız, Çelik ve Yılmaz, 2011). Extremera, Duran ve Rey, çalışmalarında, algılanan duygusal zekânın stres, yaşam doyumu, iyimserlik ve kötümserliği açıklamakta başarılı bir değişken olduğunu ortaya koymuşlardır (Extremera, Duran ve Rey, 2007). Bu çalışmada duygusal zekânın akademik iyimserlik üzerine negatif bir etkisi tespit edilmiştir. Daha evvelki çalışmalarda ele alınan iyimserlik değişkeni akademik iyimserlikle farklılık gösterebileceği gibi bu durumun daha ziyade araştırmanın dezavantajlı bir bölgede yürütülmesine bağlı olarak gelişen algı farklılıklarından kaynaklanabileceği 
düşünülmektedir. Kırsal bölgede görev yapan genç öğretmenlerin duygusal zekâ yetenekleri yükseldikçe akademik tatmin oranlarının öğrenci, veli, kurum yöneticisi, yaşanılan bölgenin altyapı olanakları ve akademik donanım gibi çevresel faktörlere ilişkin algılar doğrultusunda azalabileceği düşünülebilir.

Psikolojik dayanıklılık ölçeğinde Gürgân (2006) yılındaki çalışmasında güçlü olma, girişimci olma, iyimser olma/yaşama bağlı olma, iletişim/ilişki kurma, öngörü, amaca ulaşma, lider olma ve araştırıcı olma şeklinde sekiz alt boyut tespit etmiştir. Ancak bu çalışmada kimi boyutların birleştiği kimi boyutların da faktör analizi sonucu analizden çıkmış olduğu, böylelikle psikolojik dayanıklılığın güçlü olma ve iyimser olma/yaşama bağlı olma, araştırıcı olma ve öngörülü olma ve girişimci olma ve iletişim/ilişki kurma olmak üzere üç alt boyuttan oluştuğu görülmektedir. Dolayısıyla Gürgân'ın çalışmasında yer alan lider olma ve amaca ulaşma boyutları bu çalışmada ortaya çıkmamıştır. Bu durumun nedeni Gürgân'ın ölçeği Ankara ilinde ve üniversite öğrencileriyle test etmiş olmasına karşın, bu araştırmada ölçeğin Hakkâri il merkezi ve Yüksekova ilçesindeki öğretmenlerle test edilmiş olması, dolayısıyla mesleki ve çevresel koşulların etkisi şeklinde açıklanabilir.

Hem ulusal hem uluslararası yazında duygusal zekâ ile psikolojik dayanıklılık arasındaki ilişkiyi inceleyen birçok çalışma bulunmaktadır. Yapılan bir çalışmada hemşirelik öğrencilerinin duygusal zekâ yetenekleri ile psikolojik dayanaklıkları arasındaki ilişki incelenmiş ve duygusal zekânın psikolojik dayanıklılık üzerinde pozitif ilişkisi olduğu bulunmuştur (Büyükbayram vd. 2016). Armstrong, Galligan ve Critchley, yaptıkları çalışmada duygusal zekâ yeteneklerine sahip oldukları tespit edilen katılımcıların sevdiklerini kaybetmek, hastalık, işten atılma gibi olumsuz yaşam olaylarına karşı psikolojik dayanıklılıklarının daha yüksek olduğunu belirlemişlerdir (Armstrong, Galligan ve Critcley, 2011). Benzeri birçok çalışma da duygusal zekâ ile psikolojik dayanıklılık arasındaki pozitif yönlü ilişkiyi destekler niteliktedir. Başka bir deyişle duygusal zekâ düzeyi yüksek ve duygusal zekânın alt boyutlarına haiz bireyler hem bireysel yaşamlarında hem iş çevresi, arkadaş çevresi vb. sosyal çevreleri içerisinde yaşamsal durum ve olaylara karşı psikolojik yönden daha dayanıklı olmaktadırlar.

Duygusal zekâ alanında nadiren kullanılan bir yaklaşım, yönetimsel yaklaşımdır. Yönetimsel yaklaşım, duygusal zekânın örgütsel performansı etkilediğini ileri sürmektedir. Buna göre bir kurumda çalışanların duygusal yetenekleri ne kadar yüksekse verimlilikleri de o kadar yüksek olmaktadır. Başarı yalnızca kantitatif değerlerle değil aynı zamanda duygulara yönelik değerlerle ortaya çıkar (Côté ve Miners, 2006). Çalışma yaşamında olumlu ve olumsuz duygular, sadakat, bağlilık, aidiyet gibi tutumları ve diğerlerine yardım etme veya daha istekli çalışma gibi davranışları etkiler (Ashkanasy ve Daus, 2002). Hedefler, en iyi sosyal ve çevresel ihtiyaçların da karşılanması yoluyla başarılır (Caruso ve Salovey, 2004).

Duygusal zekânın psikolojik dayanıklılık üzerinde tespit edilen anlamlı etkisi, literatürde yer alan geçmiş çalışmaları destekler niteliktedir. Armstrong, Galligan ve Critchley'e göre duygusal zekâ yetenekleri yüksek olan bireyler, olumsuz yaşam olayları karşısında daha az stres yaşamaktadırlar, dolayısıyla bu bireylerin psikolojik olarak daha dayanıklı oldukları söylenebilir (Armstrong, Galligan ve Critchley, 2011).

Pozitif duygulara sahip bireylerin dayanıklılıklarına ilişkin çok sayıda araştırma yürütülmüştür. Buna göre pozitif duygulara sahip bireyler; enerjik, yeni deneyimlere açık ve meraklı bireylerdir. Olumsuz durumlarla başa çıkmada mizahı kullanarak duygularını yönlendirebilirler. İyimser düşünce ve esnekliğe sahip olup etkin bir biçimde sosyal ağlar edinirler. Olumlu duyguların direkt olarak dayanıklılık sağladığından söz edilemez; ancak esnek bireylerin bu özelliklerinin stresli karşılaşmalardaki tepkilerinin oluşmasında önemli işlevsel roller üstlendiği söylenebilir. Daha az dirençli bireyler, diğer meslektaşlarına kıyasla olumsuz duygusal uyarılmalardan daha hızlı etkilenmektedirler (Tugade, Fredrickson ve Barrett, 2004).

Cinsiyete dayalı farklılıkları irdeleyen geçmiş çalışmaların önemli bir kısmı kadınlarda duygusal zekâ yeteneklerinin, erkeklere göre daha yüksek olduğunu tespit etmişlerdir. Ancak Schneider, Lyons ve Khazon, kadınlarda duygusal zekâ yeteneklerinin daha yüksek olarak tespit edildiğini ve bu durumun psikolojik dayanıklılığa olumlu bir yansıması olmadığını belirtmişlerdir (Schneider, Lyons ve Khazon, 2013). 
Akademik iyimserlik ve psikolojik dayanıklılık arasında da bir ilişkinin varlığından söz etmek mümkündür. Beard, W. K. Hoy ve A. W. Hoy’a göre, akademik iyimserlik, öğretmenin öğrenciye ve veliye güvenerek öğrencinin psikolojik dayanıklılık ve azim yardımıyla zorlukların üstesinden gelebileceği ve başarılı olabileceğine dair inancıdır (Beard, Hoy ve Hoy, 2010).

Öğretmenlerin okuldaki akademik iyimserliğini ölçmek amacıyla Atilla Yıldırım ve Ercan Yılmaz tarafından yapılan 'Öğretmenlerin Okullardaki Akademik İyimserlik Algılarının Tercih Ettikleri Öğretim Stilleri Açısından İncelenmesi' adlı çalışmada, Konya örnekleminde toplam 13 okuldan 332 öğretmene uygulanmıştır. Bu çalışmada katılımcılara Çoban ve Demirtaş'ın 2011 yılında geliştirdiği "Okul Akademik İyimserlik Ölçeği” ile Sarıtaş ve Süral'in 2010 yılında Türkçeye uyarladıkları "Grasha - Reichmann Öğretme Stili Ölçeği” kullanılmıştır. Bulgulara göre katılımcı olan ögretmenlerin tercih ettikleri öğretim stilleri puanları ile akademik iyimserlik toplam puanları arasında pozitif yönlü bir ilişki belirlenmiştir (Yıldırım ve Yılmaz, 2018).

Uygulayıcılar açısından ele alındığında, araştırma sonuçları öğretmenlere ve okul yöneticilerine yol gösterici niteliktedir. İş yaşamında çoğunlukla göz ardı edilen duygusal zekâ yetenekleri ve özelliklerinin geliştirilmesine daha fazla önem verilmeli, akademik yaşamdaki kalite artırılmalı, olumsuz durum veya duyguları yönetmede duygusal zekâ devreye sokulmalıdır. Duyguların farkında olmak, esnekliği artırır. Esneklik, dinamik bir süreçtir. Olumlu duygular insanların esnek düşünme yeteneği, yaratıcı çözümler bulma ve stresli durumlarla başa çıkmada etkilidir. Bireylerin etkili başa çıkma stratejileri kullanması travmalara ve zor durumlara uyumlarını kolaylaştırır. Bu durum, onlara daha iyimser bir bakış açısı sağlar ve yaşam doyumunu artırır. İleriki çalışmalarda duygusal zekâ, akademik iyimserlik ve psikolojik dayanıklılığın öğrenciler, veliler ve okul yöneticileri gibi gruplarda da araştırılması alan yazına katkı sağlayacaktır. Bunun yanında duygusal zekâ, akademik iyimserlik ve psikolojik dayanıklılı̆̆ın performans, mesleğe bağlılık, çalışılan kuruma duyulan aidiyet gibi değişkenler üzerindeki etkilerinin incelenmesi de faydalı olabilir. 


\section{Kaynakça}

Armstrong, A. R., Galligan, R. F. ve Critchley, C. R. (2011). Emotional Intelligence and psychological resilience to negative life events. Personality and Individual Differences, 51, 331-336.

Ashkanasy, N. ve Daus, C. S. (2002). Emotion in The Workplace: The New Challenge For Managers. Academy Of Management Executive, 16 (1): 76-86.

Augusto-Landa, J. M., Pulido-Martos, m. ve Lopez-Zafra, E. (2011). Does Perceived Emotional Intelligence and Optimism/pessimism Predict Psychological Well-being? Journal of Happiness Studies, 12, 463-474.

Bariso, J. (2019). Uygulamalı Duygusal Zekâ Gerçek Hayat İçin Duygusal Zekâ Rehberi. (Çev: Hande Beyazit.) İstanbul: Sola Unitas. (Orijinal Yayın Tarihi, 2018)

Bar-On, R. (2006). The Bar-On model of emotional-social Intelligence (ESI). Psicothema, 18, 13-25.

Beard, K. S., Hoy, W. K. ve Hoy, A. W. (2010). Academic Optimism Of Individual Teachers: Confirming A New Construct. Teaching And Teaching Education, 26, 1136-1144.

Biroğul, H. K. ve Deniz, M. E. (2017). Farklı Branş Öğretmenlerinin Akademik İyimserlikleri ile Mesleki Benlik Saygılarının İncelenmesi. İlköğretim Online, 16(2), 814-825.

Bitmiş, M. G., Sökmen, A. ve Turgut, H. (2013). Psikolojik Dayanıkl1lığın Tükenmişlik Üzerine Etkisi: Örgütsel Özdeşleşmenin Aracı Rolü. Gazi Üniversitesi İktisadi ve İdari Bilimler Fakültesi Dergisi, 15 (2), 27-40.

Bozkurt, Ö. ve Ercan, A. (2017). Akademik İyimserlik ile Performans Arasındaki İlişkinin Akademisyenler Açısından Değerlendirilmesi. Uluslararası Yönetim İktisat ve Işsletme Dergisi, ICMEB17 Özel Sayıs1, 251-263.

Büyükbayram, A., Baysan Arabacı, L., Taş, G. ve Varol, D. (2016). Öğrenci Hemşirelerin Duygusal Zekâ ve Sosyotropi-Otonomi Kişilik Özellikleri ile Psikolojik Dayanıklılıkları Arasındaki İlişki. İzmir Kâtip Çelebi Üniversitesi Sağllk Bilimleri Fakültesi Dergisi, 1 (3), $29-37$.

Büyüköztürk, Ş., Kılıç Çakmak, E., Akgün, Ö. E., Karadeniz, Ş. ve Demirel, F. (2016). Bilimsel Araştırma Yöntemleri. Ankara: Pegem.

Cooper, R. K. ve Sawaf, A. (2000) Liderlikte Duygusal Zekâ. İstanbul: Sistem Yayınc1lık, 12-376.

Caruso, D. R. Ve Salovey, P. (2004). The Emotionally Intelligent Manager, How To Develop And Use The Four Key Emotional Skills Of Leadership. New Jersey: Jossey-Bass.

Côté, S. Ve Miners, C. T. H. (2006). Emotional Intelligence, Cognitive Intelligence, And Job Performance. Administrative Science Quarterly, 51: 1-28.

Crowley, B. J., Hayslip, B., ve Hobdy, J. (2003). Psychological hardiness and adjustment to life events in adulthood. Journal of Adult Development, 10(4), 237-248.

Çakar, U. ve Arbak, Y. (2004). Modern Yaklaşımlar Işı̆̆ında Değişen Duygu-Zekâ İlişskisi Ve Duygusal Zekâ. Dokuz Eylül Üniversitesi Sosyal Bilimler Enstitüsü Dergisi, 6(3), 23-48.

Çoban, D. ve Demirtaş, H. (2011). Okulların akademik iyimserlik düzeyi ile öğretmenlerin örgütsel bağlılı̆̆1 arasındaki ilişki. Kuram ve Uygulamada Eğitim Yönetimi [Educational Administration: Theory and Practice], 17(3), 317-348.

Deniz, M. E., Erus, S. M. ve Büyükcebeci, A. (2017). Bilinçli Farkındalık ile Psikolojik İyi Oluş İlişkisinde Duygusal Zekânın Aracılık Rolü. Türk Psikolojik Danışma ve Rehberlik Dergisi, 7 (47), 17-31.

Deniz, M. E., Özer, E. ve Işık, E. (2013). Duygusal zekâ özelliği ölçeği-kısa formu: Geçerlik ve Güvenirlik Çalışması. Eğitim ve Bilim, 38 (169), 407-419.

Deniz, M. E. ve Yılmaz, E. (2004). Üniversite Öğrencilerinin Duygusal Zekâ Yetenekleri ve Yaşam Doyumları Arasındaki İlişki, XIII. Ulusal Eğitim Bilimleri Kurultayı, 6-9 Temmuz İnönü Üniversitesi, Eğitim Fakültesi, Malatya, 1-9.

Durak, M. (2002). Predictive Role of Hardiness on Psychological Symptomatology of University Students Experienced Earthquake. (Yayınlanmamış Yüksek Lisans Tezi). Orta Doğu Teknik Üniversitesi, Ankara.

Durmuş, B., Çinko, M. ve Yurtkoru, E.S. (2018). Sosyal Bilimlerde SPSS'le Veri Analizi. İstanbul: Beta.

Extremera, N., Duran, A. ve Rey, L. (2007). Perceived Emotional Intelligence and dispositionaloptimism-pessimism: Analyzing their role in predictingpsychological adjustment among adolescents. Personality and Individual Differences 42, 1069-1079. 
Goleman, D. (2007). Duygusal Zekâ EQ Neden IQ'dan Daha Önemlidir? (Çev: Banu Seçkin Yüksel) Varlık Yayınları, İstanbul. (Orijinal yayın tarihi,1996) 31, 20- 390.

Goleman, D. (2019). İşbaşında Duygusal Zekâ (Çev: Handan Balkara) Varlık Yayınları, İstanbul. (Orijinal yayın tarihi, 1998) 19, 10-389

Goleman, D. (2019). Duygusal Zekâ ve Liderlik, Optimist, İstanbul. 1, 10-97.

Gillham, J. ve Reivich, K. (2004). Cultivating optimism in childhood and adolescence. The ANNALS of the American Academy of Political and Social Science, 591, 146-163. doi: $10.1177 / 0002716203260095$.

Gürgân, U. (2006). Yılmazlık Ölçeği (YÖ): Ölçek Geliştirme, Güvenirlik ve Geçerlik Çalışması. Ankara Üniversitesi Eğitim Bilimleri Fakültesi Dergisi, 39(2), 45-74.

Henderson, A. T., \& Mapp, K. L. (2002). A new wave of evidence: The impact of school, family, and community connections on student achievement. Austin, TX: Southwest Educational Development Laboratory, National Center for Family \&Community Connections with Schools, 19-20.

Hanton, S., Evans, L. ve Neil, R. (2003). Hardiness and the Competitive Trait Anxiety Response. Anxiety, Stress and Coping, 16(2), 167-184.

Hoy, A. W., Hoy, W. K. ve Kurz, N. M. (2008). Teacher's academic optimism: The development and test of a new construct. Teaching and Teacher Education, 24, 821-835.

Hoy, W. A. (2010). Eğitim Psikolojisi (Çev.: Duygu Özen), Kaknüs Yayınları, İstanbul, 46.

Işı1k, Ş. (2016). Psikolojik Dayanıklılık Ölçeği'nin geliştirilmesi: Geçerlik ve güvenirlik çalışması. The Journal of Happiness \& Well-Being, 4 (2), 165-182.

Kanbur, E., Kanbur, A. ve Özdemir, B. (2017). Psikolojik Dayanıklılık İle Örgütsel Vatandaşlık Davranışı Arasındaki İlişside İş Doyumunun Aracılık Rolü: Havacılık Sektöründe Bir Araştırma. İş ve İnsan Dergisi, 4 (2), 127-141.

Karacaoğlu, K. ve Köktaş, G. (2016). Psikolojik Dayanıklılık ve Psikolojik İyi Olma İlişkisinde İyimserliğin Aracı Rolü: Hastane Çalışanları Üzerine Bir Araştırma. Işs ve İnsan Dergisi, 3(2), 119-127.

Kayac1, Ü. ve Özbay, Y. (2016). Üniversite öğrencilerinin travmatik yaşant1, psikolojik doğum sıralar1 ve sosyal ilgilerinin psikolojik dayanıkl11klarını yordamas1. The Journal of Happiness \& WellBeing, 4(1), 128-142.

Kerimgil, Ç. S. ve Gürol, M. (2013). Akademik Iyyimserlik Ölçeğinin Türkçe’ye Uyarlanması, 1. Uluslararası Eğitim Programları ve Öğretim Kongresi.

Kumcagiz H., Celik B.S. , Yilmaz M. ve Eren Z. ( 2011). The effects of Emotional Intelligence on optimism of university students. Procedia - Social and Behavioral Sciences, 30 (2011) 973 977.

Küçükahmet, L. (2010). Eğitim Bilimine Giriş. Nobel Yayınevi: Ankara, 11, 182-192.

Kirby, M. M. (2009). Academic optimism and community engagement in urban elementary schools. (Yayınlanmamış Doktora Tezi). College of William and Mary: Williamsburg.

Motan, İ. ve Gençöz, F. (2009). Psikolojik Dayanıklılığı Nasıl Ölçebiliriz? Bir Türk Örnekleminde Kişisel Görüş Ölçeği-II'nin Geçerlik ve Güvenilirlik Çalışması. Kriz Dergisi, 17 (1), 1-11.

Ngidi, D. P. (2012). Academic Optimism: An Individual Teacher Belief. Educational Studies, 38 (2), $139-150$.

Özden, Y. (2014). Öğrenme ve Öğretme, Pegem Akademi: Ankara, 7, 15.

Rey, L. ve Extremera, N. (2014). Positive psychological characteristics and interpersonal forgiveness: Identifying the unique contribution of Emotional Intelligence abilities,Big Five traits, gratitude and optimism. Personality and Individual Differences, 68, 199-204.

Salovey, P. ve Mayer, J.D. (1989-1990). Emotional Intelligence. Imagination, Cognition And Personality, 9(3), 185-211.

Sarkar, M. Ve Fletcher, D. (2014). Psychological resilience in sport performers: a review of stressors and protective factors. Journal of Sports Sciences, 32 (15), 1419-1434, DOI: 10.1080/02640414.2014.901551.

Selçuk, Z. (2018). Eğitim Psikolojisi, Nobel: Ankara, 23, 47.

Schneider, T. R., Lyons, J. B. ve Khazon, S. (2013). Emotional Intelligence and Resilience. Personality And Individual Differences, 1-5. 
Stewart, M., Reid, G. \& Mangham, C. (1997). Fostering children's resilience. Journal of Pediatric Nursing, 12, 21-31.

Terzi, Ş (2008). Üniversite Öğrencilerinin Psikolojik Dayanıklılıkları ve Algıladıkları Sosyal Destek Arasındaki İlişki. Türk Psikolojik Danışma ve Rehberlik Dergisi, 3 (29), 1-11.

Tugade, M. M., Fredrickson, B. L. ve Barrett, L. F. (2004). Psychological Resilience And Positive Emotional Granularity: Examining The Benefits Of Positive Emotions On Coping And Health. Journal of Personality, (6), 1161-1190.

Woolfolk, A. (2010). Educational psychology. Pearson, USA, 11, 1136.

Windle, G., Markland, D. A. ve Woods, R.T. (2008). Examination of a theoretical model of psychological resilience in older age. Aging \& Mental Health, 12 (3), 285-292.

Yeşilyaprak, B. (2001). Duygusal Zekâ ve Eğitim Açısından Doğurguları. Kuram ve Uygulamada Eğitim Yönetimi, 25, 139-146.

Yıldırım A. ve Yılmaz E. (2018) Öğretmenlerin Okullardaki Akademik İyimserlik Algılarının Tercih Ettikleri Öğretim Stilleri Açısından İncelenmesi. Journal of Human Sciences, 1624-1625. 


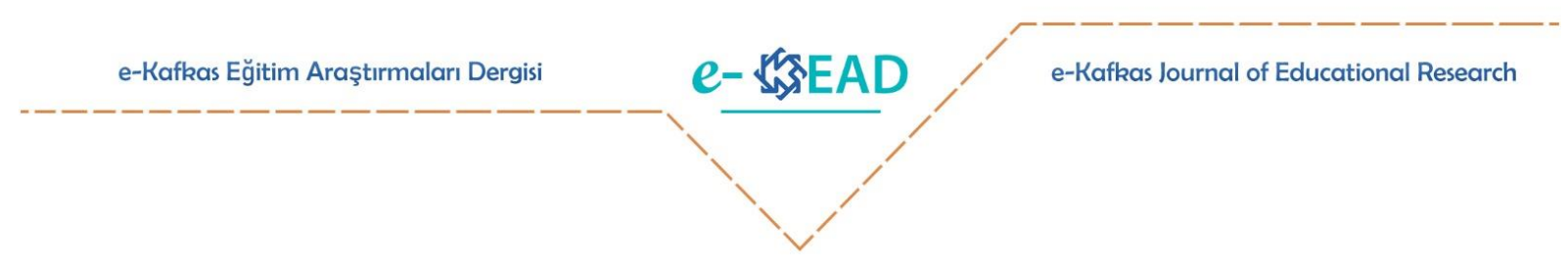

\section{The Effect of Emotional Intelligence Skills on Academic Optimism and Psychological Resilience in Different Branch Teachers}

\section{Abdurrahman Kasım PAKIŞ}

Mehmet Engin DENIZ

To cite this article: Pakiş, A. K. ve Deniz, E. M. (2020). Farklı branş öğretmenlerinin duygusal zeka yeteneklerinin akademik iyimserlik ve psikolojik dayanıklılık üzerine Etkisi, e-Kafkas Araştırmaları Dergisi, 7 , 153-166. doi:10.30900/kafkasegt.752595

\section{Research article}

Received: 13.06 .2020
Accepted:09.07.2020

\section{Introduction}

Teachers, as individuals who shape the lives of a society, even all of humanity, are expected to have high levels of Intelligence in terms of emotional as well as cognitive. To date, the benchmark for cleverness has mostly been the level of cognitive Intelligence. Emotional Intelligence has been overshadowed by cognitive Intelligence in all areas, including the teaching profession. However, perhaps the most important problem in today's society has been that Emotional Intelligence has not been adequately cared for. People who have become aware of this situation have begun to value Emotional Intelligence more and more in social life.

The concept of academic optimism, which has found its place in positive psychology studies, is another subject that is examined within the scope of this study. Academic optimism is significantly influenced by teachers' expectations and perceptions of environmental factors, such as their colleagues, the institution, their managers, and the educational system they are in.

The teaching profession is perhaps the most popular area in society. The teacher plays an active role in preparing the students for life, as well as giving knowledge and skills academically. The teacher is involved not only in the academic and personal development of the students but also, especially health status, family life, etc. All these obligations can be a source of stress for the teacher. In this study, the effect of Emotional Intelligence on academic optimism and psychological resilience in different branch teachers has been researched.

\section{Method}

Research design is an example of the type of survey research. This is definitional research in that it reveals the current situation. As a sampling method, the convenience sampling method was preferred with time and cost constraints in mind. Within the scope of the research, 709 teachers working in Hakkâri Central and Yüksekova districts were reached. Data were collected by the face-toface survey method in the study using the quantitative method. Statistical methods used in data analysis were frequency distribution and linear regression. This research covered only the Yüksekova district and the central district in Hakkâri province. Besides, due to the outbreak of Covid 19, which occurred during data collection, a severe time constraint was encountered. Since a face-to-face questionnaire was applied to teachers working in the Ministry of education, it was not possible to continue collecting data during the transition to distance education. At first, the frequency distributions were examined to reveal the demographic characteristics of the participants in the study. Then, simple linear regression analysis was performed to test the effect of Emotional Intelligence on academic optimism and psychological resilience. According to the research, 9.2\% of academic optimism was 
explained by Emotional Intelligence. The effect of Emotional Intelligence on academic optimism was found to be negative. $27.5 \%$ of psychological resilience was explained by Emotional Intelligence.

\section{Discussion, Conclusion, and Recommendations}

When it comes to intelligence, people often think of IQ-Intelligence quotient. Being intelligent is similarly associated with higher levels of cognitive Intelligence. However, Emotional Intelligence which is another dimension of Intelligence is as important as cognitive Intelligence. Emotional Intelligence is linked to managing our emotions in our internal and external relationships. An individual with a high level of cognitive intelligence may not have equal levels of Emotional Intelligence. This situation has become perhaps one of the biggest problems in today's society. We see that cognitive Intelligence is highly valued in school, workplace, and other social groups, starting with family in the individual's childhood. However, Emotional Intelligence is as important as cognitive intelligence, or even greater than it is. There have been no studies in the literature directly on the effect of Emotional Intelligence on academic optimism. But the correlation between Emotional Intelligence and optimism has often been addressed. In this study, which examined the effects of Emotional Intelligence on academic optimism and psychological endurance in different branch teachers, it was observed that Emotional Intelligence had negative effects on academic optimism and positive effects on psychological endurance.

It can be thought that their academic satisfaction rates may decrease in line with perceptions of difficult environmental factors such as student, parent, institution manager, infrastructure opportunities of the living area, and academic equipment since the Emotional Intelligence abilities of some new young teachers in rural areas are very high. For practitioners, the results of the research are guiding teachers and school administrators. More attention should be given to the development of Emotional Intelligence abilities and characteristics that are often overlooked in business life, that quality in academic life should be increased, and that Emotional Intelligence should be put into action in managing negative situations or emotions. Positive emotions play an effective role in people's ability to think flexibly, find creative solutions, and deal with stressful situations. These provide them a more optimistic outlook and increase their life satisfaction. In future studies, the study of Emotional Intelligence, academic optimism, and psychological resilience in different groups such as students, parents, and school administrators will add more contribution to the research field. Also, it may be useful to examine the effects of Emotional Intelligence, academic optimism, and psychological resilience on variables such as performance, commitment to the profession, belonging to the institution. 